Site of «Scilab is recognized as having educational value by the French Department of Education». (2011). Rocquencourt, July 26 $6^{\text {th }}$ 2011. Online. URL: https://www.scilab.org/content/download/514/4351/file/CP_Scilab_26072 011_eng.pdf [in English].

Site of «Scilab Online». (2018). URL: https://www.rollapp.com/app/scilab [in English].

Sobolj, Y. M. (1968). Metod Monte-Karlo [Monte Carlo method]. Moskva : Nauka [in Russian].

Tkachuk, V. V., Shchokin, V. P. \& Tron, V. V. (2018). The Model of Use of Mobile Information and Communication Technologies in Learning Computer Sciences to Future Professionals in Engineering Pedagogy, CEUR Workshop Proceedings, 2257, 103-111 [in English].

Site of «Web application - Scilab.io». (2016). URL: https://scilab.io/services/development/web-application [in English].

Site of «Xcos». (2019). URL : http://xcos.fossee.in [in English].

удк $378 ; 37.003 .42$

DOI: https://doi.org/10.35387/od.2(18).2020.115-122

Товканець Ганна Василівна - доктор педагогічних наук, профресор, завідувач кафедри теорії та методики початкової освіти Мукачівського державного університету

ORCID ID https://orcid.org/0000-0002-6191-9569

E-mail: tovkanec2017@gmail.com

\title{
ПІДГОТОВКА МАЙБУТНІХ ПЕДАГОГІВ ДО ВИХОВАННЯ ДІТЕЙ-СИРІТ В УМОВАХ СОЦІАЛЬНИХ ТРАНСФОРМАЦІЙ
}

Анотація. Оглядову публікацію присвячено проблемі підготовки майбутніх педагогів до виховання дітей-сиріт в умовах соціальних трансорормацій. В статті обгрунтовано напрями підготовки майбутніх педагогів до виховання дітей-сиріт в умовах соціальних трансформацій. Визначено готовність майбутніх педагогів до роботи з дітьмисиротами як особистісне утворення, що передбачає наявність професійно важливих якостей та характеризується спрямованістю на успішну взаємодію з вихованцями. Підкреслено, що напрямами профресійної підготовки майбутніх педагогів в умовах соціальних трансфрормацій $є$ : акцент на розробку програм соціального виховання $в$ освітніх навчальних закладах, врахування активно-діяльнісної природи дитини-сироти, ї̈ прагнення до участі в ціннісно-значимій, креативнодослідній, індивідуально-комфортній життєдіяльності; спрямування соціально-педагогічної діяльності на формування адекватних иіннісних орієнтацій, соціального досвіду, установок на досягнення соціальнопсихологічного комфорту; вивчення законодавчо-нормативного забезпечення; впровадження конструктивних ідей зарубіжного досвіду 
утримання дітей-сиріт з акцентуванням проблем щодо створення оптимальних умов для підтримки соціально незахищених категорій дітей як одного з найважливіших завдань сьогодення. Окреслено практичний аспект у підготовці майбутнього вчителя до соціальнопедагогічної взаємодії з дітьми-сиротами: формування умінь і навичок здійснення педагогічних операцій, сукупність яких складає процедуру технологічного процесу освітньої діяльності; виявлення, оцінки та ранжування проблеми, з'ясування чинників, що обумовили ї̈ виникнення; спрямування практичного навчання на здійснення аналізу взаємодії, для вироблення програм дій, складання змістовної бази для уточнення мети та завдань, визначення організаційних форм і методів соціальнопедагогічної роботи з дітьми-сиротами; реалізація намічених програмою заходів соціально-педагогічного впливу в означений час $і$ терміни, зіставлення $i$ порівняння результатів з критеріями успішності соціально-педагогічної діяльності; підготовка до здійснення контролю, аналізу підсумків діяльності, виявлення чинників, які сприяють позитивному вирішенню завдань соціально-педагогічної діяльності $з$ дітьми-сиротами і проектуванню шляхів усунення недоліків тощо.

Ключові слова: профресійна підготовка, майбутній педагог, виховання дітей-сиріт.

Tovkanets Hanna - Doctor of Pedagogical Sciences, Professor, Head of the Pedagogy and Methodology of Preschool and Primary Education Chair, Mukachevo State University

ORCID ID https://orcid.org/0000-0002-6191-9569

E-mail: tovkanec2017@gmail.com

\section{PREPARATION OF FUTURE TEACHERS FOR THE EDUCATION OF ORPHAN CHILDREN IN THE CONDITIONS OF SOCIAL TRANSFORMATIONS}

Abstract. The publication is devoted to the analysis of the problem of preparation of future teachers for the upbringing of orphans in the conditions of social transformations. The article substantiates the directions of preparation of future teachers for the upbringing of orphans in the conditions of social transformations. The readiness of future teachers to work with orphans as a personal education is determined, which presupposes the presence of professionally important qualities and is characterized by a focus on successful interaction with students. It is emphasized that the areas of professional training of future teachers in terms of social transformations are: emphasis on the development of social education programs in educational institutions, taking into account the active nature of the orphan, its desire to participate in value-based, creative and research, individual and comfort vital activity; direction of sociopedagogical activities on the formation of adequate value orientations, social 
experience, attitudes to achieve socio-psychological comfort; study of legislative and regulatory support; introduction of constructive ideas of foreign experience in providing orphans with emphasis on the problems of creating optimal conditions for the support of socially vulnerable categories of children as one of the most important tasks of today.

The practical aspect in preparation of the future teacher for social and pedagogical interaction with orphans is outlined: formation of abilities and skills of realization of pedagogical operations which set makes procedure of technological process of educational activity: identification, estimation and ranking of a problem, clarification of the factors which have caused its occurrence; directing practical training to the analysis of interaction, to develop action programs, compile a meaningful basis for clarifying the goals and objectives, determining the organizational forms and methods of sociopedagogical work with orphans; implementation of the measures of social and pedagogical influence planned by the program in the specified time and terms, comparison of results with criteria of success of social and pedagogical activity; preparation for control, analysis of the results of activities, identification of factors that contribute to the positive solution of the problems of sociopedagogical activities with orphans and the designing ways to eliminate shortcomings, etc.

Key words: professional training, future teacher, education of orphans.

Постановка проблеми, її актуальність. Прогресивні зміни, що відбуваються сьогодні в державній освітній політиці, тенденційно позначаються на системі виховання дітей та підготовці педагогів до виховної роботи. Стратегії її вдосконалення законодавчо відображено в Законах України «Про освіту» (2017), «Про вищу освіту» (2014), Національній стратегії розвитку освіти в Україні на період до 2021 року (2013), Національній стратегії реформування системи інституційного догляду та виховання дітей на 2017-2026 рр. (2017), Стратегії розвитку вищої освіти в Україні на 2021-2031рр. (2020).

Розвиток вітчизняної педагогічної освіти детермінований нормативно-правовими документами: Концепцією реалізації державної політики у сфрері реформування загальної середньої освіти «Нова українська школа» (2017), Концепцією розвитку педагогічної освіти (2018).

Сучасні тенденції, спрямовані на модернізацію системи педагогічної освіти, вимагають удосконалення процесу професійного зростання студентів, нових шляхів підвищення їх фрахової підготовки, зокрема щодо проблем виховання дітей.

Аналіз останніх досліджень і публікацій. Проблеми професійної підготовки фахівців із педагогіки знайшли своє відображення в роботах С. Архипової, О. Безпалько, М. Васильєвої, І. Звєрєвої, А. Капської, О. Карпенко, І. Ковчиної, Г. Лактіонової, Л. Міщик, С. Харченко та ін. 
Комплекс питань професійної підготовки майбутніх педагогів щодо організації соціально-виховної роботи з дітьми-сиротами представлено в роботах Л. Артюшкіна, Л. Боднар, О. Гура, О. Кириченко, В. Поліщук, О. Холостова та ін. Наукові підходи до виховання суспільно-активної особистості дитини-сироти, фрорми та методи соціально-педагогічної роботи з такою дитиною, формування її компетентностей висвітлено у працях В. Завгязинського, С. Курінної, І. Манохіної, В. Мухіної, Н. Павлик, І. Пєша та ін. Технологічний підхід соціально-педагогічної роботи з дітьмисиротами в різних закладах досліджували Л. Завацька, І. Манохіна, І. Трубавіна, С. Харченко, Т. Шайдо та ін. Водночас проблема підготовки майбутніх педагогів до виховання дітей-сиріт, на нашу думку, $€$ недостатньо дослідженою, що й зумовило предмет дослідження.

Мета статті полягає в обґрунтуванні напрямів змістової підготовки майбутніх педагогів до виховання дітей-сиріт в умовах сучасних соціальних трансформацій.

Виклад основного матеріалу дослідження. Насамперед зазначимо, що готовність майбутнього педагога до роботи 3 дітьмисиротами $є$ особистісним утворенням, що передбачає сформованість системи спеціальних знань, умінь і навичок, наявність профресійно важливих якостей та характеризується спрямованістю на успішну взаємодію й допомогу (Манохіна, 2012), а також спроможністю протидіяти перешкодам, що виникають у процесі роботи з такими дітьми.

В умовах сучасних соціальних трансформацій підготовка майбутніх педагогів $є$ освітнім процесом, орієнтованим на послідовне, системне та цілеспрямоване засвоєння професійних знань на основі введення нових освітніх стандартів, інноваційних форм та методів навчання у відповідності до запиту суспільства. Вивчення порушеної проблеми засвідчує, що завданнями такої підготовки $\epsilon$ сприяння оволодінню навичками та методичними принципами виховної роботи, формування позитивного ставлення та емоційного сприйняття студентами професійної діяльності 3 дітьми-сиротами. Власне, процес формування готовності передбачає формування громадської активності, соціальної відповідальності й громадянської позиції у роботі з дітьми-сиртами, формування постійної потреби у науковому підході до педагогічної роботи, до створення морально-правового освітнього простору.

Аналіз науково-педагогічних досліджень (Енциклопедія освіти, 2008; Манохіна, 2012; Терновая, 2009) і нормативно-правових документів (Національна стратегія реформування, 2017; Стратегія розвитку вищої освіти, 2020) дає підставу виокремити декілька напрямів, на яких варто зосередити увагу у процесі професійно-педагогічної підготовки майбутніх педагогів до роботи з дітьми-сиротами. До них ми відносимо:

- вивчення законодавчо-нормативного забезпечення, враховуючи положення документів міжнародного рівня, зокрема Конвенції ООН про право кожної дитини на сімейне виховання, Конвенції про контакт з дітьми, 
Європейської конвенції про визнання та виконання рішень стосовно опіки над дітьми та про поновлення опіки над дітьми, Європейської конвенції про здійснення прав дітей, Європейської конвенції про усиновлення дітей, Конвенції про захист дітей та співробітництво в галузі міждержавного усиновлення, Сімейного кодексу України, положення нормативно-правової бази для практичного запровадження патронату, волонтерства тощо, зокрема Концепції громадянської освіти та виховання в Україні (2012), національно-патріотичного виховання дітей та молоді (2015) і Національної стратегії реформування системи інституційного догляду та виховання дітей на 2017-2026 роки (2017), яка декларує нові пріоритети в забезпеченні й вихованні дітей в умовах євроінтеграційних процесів;

- акцент на розробленні програм соціального виховання в освітніх навчальних закладах, вивчення активно-діяльнісної природи дитинисироти, її прагнення до участі в ціннісно-значимій, креативно-дослідній, індивідуально-комфортній життєдіяльності (Енциклопедія освіти, 2008);

- спрямування соціально-педагогічної діяльності на формування адекватних ціннісних орієнтацій, соціального досвіду, установок на досягнення соціально-психологічного комфорту;

- упровадження конструктивних ідей зарубіжного досвіду забезпечення дітей-сиріт з акцентуванням проблем щодо створення оптимальних умов для підтримки соціально незахищених категорій дітей як одного з найважливіших завдань сьогодення, яке полягає не в ізоляції знедолених дітей, а в їх інтеграції в соціум через пріоритетність у соціальній політиці саме сімейних форм допомоги дітям-сиротам. Зокрема це стосується такого досвіду Румунії, Угорщини, Словаччини, Швеції, США та Великобританії. Курс України на європейську інтеграцію зумовлює перегляд пріоритетів державної політики у сфері охорони дитинства, впровадження успішних підходів із світової практики захисту прав дітей, які базуються на забезпеченні прав і найкращих інтересів дитини, спрямовуються на підтримку сім'ї, створення умов для виховання та розвитку дітей у сім'ї або середовищі, максимально наближеному до сімейного.

Практичний аспект підготовки майбутнього вчителя до соціальнопедагогічної взаємодії з дітьми-сиротами, на нашу думку, передбачає:

- розробку програм практики соціально-педагогічної роботи у відповідності до вимог сучасного рівня суспільного розвитку;

- формування умінь і навичок здійснення педагогічних операцій (прості дії, спрямовані на досягнення конкретної усвідомленої цілі), сукупність яких складає процедуру технологічного процесу освітньої діяльності: виявлення, оцінка та ранжування проблеми, з'ясування чинників, що обумовили її виникнення (Манохіна, 2012);

- спрямування практичного навчання на здійснення аналізу результатів взаємодії, складання змістовної бази для уточнення мети та завдань, для вироблення програми дій, визначення організаційних форм і 
методів соціально-педагогічної роботи з дітьми-сиротами;

- підготовку до здійснення контролю, аналізу підсумків діяльності, виявлення чинників, які сприяють позитивному вирішенню завдань соціально-педагогічної діяльності з дітьми-сиротами і проектуванню шляхів усунення недоліків;

- використання у процесі підготовки студентів комплексу вправ професійної спрямованості, потенціалу педагогічної практики і самостійної роботи, що забезпечується єдністю різних форм навчання, взаємозв'язком лекційних, семінарських та лабораторно-практичних занять у процесі педагогічної практики та самостійної роботи (Товканець, 2019).

Удосконалення змісту професійно-педагогічної підготовки студентів на основі максимального врахування особливостей особистості дитини передбачає засвоєння студентами взаємозв'язку рис характеру дітей-сиріт і особливих умов їх психічного розвитку; проведення соціальнопсихологічних тренінгів з метою актуалізації знань про особливості таких дітей; ознайомлення й обмін новою інформацією та висновками досліджень, проведених на замовлення ЮНІСЕФ, закладів системи Державного комітету України у справах сім'ї і молоді, громадських і міжнародних організацій; зміну сформованих установок та засвоєння нових; формування толерантності стосовно соціальних сиріт, умінь прогнозувати негативні поведінкові вияви з боку дітей вулиці та запобігати їм; поглиблене засвоєння майбутніми фахівцями негативних аспектів соціалізації дітей-сиріт.

Не менш актуальним $€$ залучення студентів до колективного обговорення проблем виховного процесу з дітьми-сиротами, складених на матеріалах реальних життєвих ситуацій, що сприяє усвідомленню студентами власного погляду на проблему сирітства, розвитку ініціативи, виробленню звички відокремлювати важливе від другорядного, удосконаленню вміння формулювати проблеми; розвиває комунікативні якості й уміння критичного мислення, навчає студентів аналізу реальних фактів, прищеплює вміння слухати і взаємодіяти з іншими учасниками, моделювати особливо складні професійні ситуації, а також враховувати багатозначність адекватних рішень і створення психологічно позитивного освітнього середовища.

Висновки і перспективи подальших досліджень. Готовність майбутніх педагогів до виховання дітей-сиріт $€$ складним особистісним утворенням, що виявляється у сукупності організаційних і професійноприкладних здібностей, спрямованих на соціалізацію й адаптацію дітейсиріт із урахуванням їх індивідуальних здібностей. Результатом роботи 3 підготовки до роботи з дітьми-сиротами є сформовані когнітивні, правові, операційно-технологічні, етичні, соціальні та поведінкові компетенції.

Перспективи подальших досліджень вбачаємо у дослідженні впливу науково-дослідної роботи майбутніх педагогів на формування професійних компетенцій щодо роботи з дітьми-сиротами. 


\section{Список використаних джерел}

Енциклопедія освіти. (2008) В.Г. Кремень (голов. ред.). К. : Юрінком Інтер. 1040.

Манохіна, І.В. (2012) Соціально-педагогічна робота з дітьми-сиротами та дітьми, позбавленими батьківського піклування: навчальний посібник. Дніпропетровськ: Дніпропетровський університет імені Альфреда Нобеля. 276.

Національна стратегія реформування системи інституційного догляду та виховання дітей на 2017 - 2026 роки (2017). URL: https: zakon.rada.gov.ua/laws/show/526-2017-\%D1\%80\#Text

Стратегія розвитку вищої освіти в Україні на 2021-2031 роки (2020). URL: http: www.reform.org.ua/proj_edu_strategy_2021-2031.pdf

Терновая, И.П. (2009) Подготовка студентов к социально-педагогической работе с детьми-сиротами и детьми, оставшимися без попечения родителей. Современные проблемы науки и образования. 6. URL: http://www.science-education.ru/ru/article/view?id=1337

Товканець, Г.В. (2019) Завдання соціально-педагогічної роботи з учнями молодшого шкільного віку в умовах Нової української школи. Соціологія та соціальна робота в умовах національних та регіональних викликів: матеріали доповідей та повідомлень Міжнародної науково-практичної конференції. Ред.: І.В. Козубовська, Ф.Ф. Шандор. Ужгород: ТОВ «РІК-У». 100-102.

References (translated and transliterated)

Entsyklopediia osvity [Encyclopedia of Education]. (2008) V. H. Kremen (holov. red.). K. : Yurinkom Inter. 1040 [in Ukrainian].

Manokhina, I.V. (2012) Sotsialno-pedahohichna robota z ditmy-syrotamy ta ditmy, pozbavlenymy batkivskoho pikluvannia [Socio-pedagogical work with orphans and children deprived of parental care]: navchalnyi posibnyk. Dnipropetrovsk: Dnipropetrovskyi universytet imeni Alfreda Nobelia. 276 [in Ukrainian].

Natsionalna stratehiia reformuvannia systemy instytutsiinoho dohliadu ta vykhovannia ditei na 2017 - 2026 roky (2017) [National strategy for reforming the institutional care system and upbringing of children for 20172026]. URL: https://zakon.rada.gov.ua/laws/show/526-2017-\%D1\%80\#Text [in Ukrainian].

Stratehiia rozvytku vyshchoi osvity v Ukraini na 2021-2031 roky (2020) [Strategy for the development of higher education in Ukraine for 2021-2031]. URL: http://www.reform.org.ua/proj_edu_strategy_2021-2031.pdf [in Ukrainian].

Ternovaya, I.P. (2009) Podgotovka studentov k sotsialno-pedagogicheskoy rabote s detmi-sirotami i detmi, ostavshimisya bez popecheniya roditeley [Preparing students for social and pedagogical work with orphans and children left without parental care]. Sovremennyie problemyi nauki i obrazovaniya. 6. URL: http://www.science-education.ru/ru/article/view?id=1337 [in Russian].

Tovkanets, H.V. (2019) Zavdannia sotsialno-pedahohichnoi roboty z uchniamy 
molodshoho shkilnoho viku $v$ umovakh Novoi ukrainskoi shkoly [Tasks of social and pedagogical work with primary school students in the New Ukrainian school.]. Sotsiolohiia ta sotsialna robota $v$ umovakh natsionalnykh ta rehionalnykh vyklykiv: materialy dopovidei ta povidomlen Mizhnarodnoi naukovo-praktychnoi konferentsii. Red. I.V. Kozubovska, F.F. Shandor. Uzhhorod: TOV «RIK-U». 100-102 [in Ukrainian].

УдК 378.046.4: 373.58/.5.091.2.011.3-051:51]:004

DOI: https://doi.org/10.35387/od.2(18).2020.122-130

Шишкіна Марія Павлівна - доктор педагогічних наук, старший науковий співробітник, завідувач відділу хмаро орієнтованих систем інфоорматизації освіти Інституту інфрормаційних технологій $і$ засобів навчання НАПН України

ORCID iD: $h$ ttp://orcid.org/0000-0001-5569-2700

E-mail: shyshkina@iittt.gov.ua

\title{
ОРГАНІЗАЦІЯ НАВЧАЛЬНОГО Й НАУКОВОГО СПІВРОБІТНИЦТВА У ВІРТУАЛЬНИХ СИСТЕМАХ ВІДКРИТОЇ НАУКИ У ЗАКЛАДАХ ВИЩОЇ ОСВІТИ
}

\begin{abstract}
Анотація. У статmі розглянуто особливості фрормування віртуальних систем відкритої науки у закладах вищої освіти, що $\epsilon$ суттєвою передумовою підготовки IКТ-компетентних фрахівців, здатних до активного, доцільного, науково обгрунтованого застосування найсучасніших IKT у своїй профресійній діяльності. У результаті дослідження уточнено поняттєвий апарат; виявлено перспективи та сучасні європейські тенденції формування хмаро орієнтованих систем відкритої науки у закладах вищої освіти; визначено перспективні шляхи застосування хмаро орієнтованих платорорм $і$ адаптивних сервісів управління контентом у діяльності викладавча, науковия; узагальнено досвід впровадження окремих сервісів хмаро орієнтованих систем відкритої науки у процесі підтримування наукового співробітництва у закладах вищої освіти. Встановлено, що завдяки ширшому залученню в освітній у процес закладів вищої освіти засобів і сервісів науково-освітніх хмаро орієнтованих платформ, а також різних типів корпоративних хмарних сервісів вдається досягти позитивних змін у здійсненні навчальної $і$ наукової діяльності, поліпшенні ї якісних $і$ кількісних показників, застосуванні нових фрорм і моделей ї̈ організації, що позитивно впливає як на результати навчання, так $і$ на розвиток наукових досліджень, поліпшення рівня їх організації, підвищення ефективності. Узагальнено досвід використання відкритих хмаро орієнтованих систем відкритої науки для підтримування комунікації; спільної роботи; адаптивного управління контентом; створення $i$
\end{abstract}

